\title{
Verbal fluency in categories of common and proper names in the phase of mild cognitive impairment in the course of Parkinson's disease
}

\begin{abstract}
Renata Gliwa, Verbal fluency in categories of common and proper names in the phase of mild cognitive impairment in the course of Parkinson's disease. Interdisciplinary Contexts of Special Pedagogy, no. 27, Poznań 2019. Pp. 249-272. Adam Mickiewicz University Press. ISSN 2300-391X. e-ISSN 2658-283X. DOI: https:// doi.org/10.14746/ikps.2019.27.12

The article is devoted to consideration of verbal fluency in MCI-PD. The VF test allows for the detection of dysfunctions within linguistic processes, semantic memory and dysfunctions of executive functions already in the early stages of Parkinson's disease. The article compares the results of verbal fluency tests in selected categories of proper names and common names, and assesses the effect of the MCIPD stage on the test result. The comparison of the test group results with various degrees of MCI indicates a progressive decrease in verbal fluency. The experiment showed different profiles of the verbal task in terms of common and proper names.
\end{abstract}

KEY WORDS: nomina propria, nomina appellativa, semantic category, verbal fluency test, mild cognitive impairment in Parkinson's disease 


\section{Introduction}

Words that constitute the basis of verbal communication create a so-called mental dictionary that contains cognitive diagrams understood as knowledge on stimuli ordered by category. The resources of the dictionary are collected with varied intensities as a result of acquisition of linguistic and extralinguistic experience throughout an individual's life. The more frequently one uses data related to specific semantic categories in daily life, the better access they have to them. ${ }^{1}$

The state of the semantic dictionary is indicated, among others, the capacity to recall words as needed - so-called verbal fluency. ${ }^{2}$ One of the most reliable tools used to assess it is the verbal fluency test (VF test) ${ }^{3}$. This test was created to assess the mental productivity of persons with damage to the CNS. Its completion requires one to list as high a number of words according to a specific criterion, e. g. formal (words beginning with a specific sound) or semantic (belonging to a specific semantic category). ${ }^{4}$

${ }^{1}$ Conf. E. Zawadzka, Świat w obrazach u osób po udarze mózgu, Wydawnictwo DIFIN, Warszawa 2013, p. 17.

2 Conf. E. Łuczywek, E. Fersten, Poziom fluencji słownej przy różnych uszkodzeniach mózgu, „Studia Psychologiczne” 1992, no. XXX, pp. 89-98; E.M. Szepietowska, B. Gawda, Ścieżkami fluencji werbalnej, Wydawnictwo UMCS, Lublin 2011, p. 7.

3 The TFS, Thurstone's Word Fluency Test, was developed by L.L. Thurstone in the first half of the 20th century (conf. L.L. Thurstone, Mental abilities, Chicago 1938; conf. also M. Piskunowicz, M. Bieliński, A. Zgliński, A. Borkowska, Testy fluencji stownej - zastosowanie w diagnostyce neuropsychologicznej, "Psychiatria Polska” 2013, no. XLVI, 3, pp. 475-476).

${ }^{4}$ Due to the frequency of words in a given language, one distinguishes between broad categories (sets of words connected in a certain manner, e. g. semantically or phonetically, strongly represented in the mental dictionary of the members of a society, e. g. animal names; or narrow categories - sets of words with statistically limited representation in the mental dictionary, e. g. names of sharp objects (conf. E. Łuczywek, E. Fersten, op. cit., p. 93; M. Ponichtera-Kasprzykowska, T. Sobów, Adaptacja $i$ wykorzystanie testu fluencji stownej na świecie, „Psychiatria i Psychologia Kliniczna" 2014, 14(3), p. 180). On various types of fluence see e. g. E.M. Szepietowska, B. Gwda (Ścieżkami..., op. cit., pp. 8-9). 
The correct execution of the test is possible thanks to the interaction of several factors: Efficient execution mechanisms ${ }^{5}$, developed semantic networks binding concepts into specific sets, an efficient lexical activation mechanism ${ }^{6}$ and the fundamental capacity of understanding verbal messages. ${ }^{7}$ The mode of execution of tasks dealing with verbal fluency (e.g. the choice of the name search strategy ${ }^{8}$ ) indicates the quality of linguistic processes, the state of semantic memory and the efficiency of execution processes/ functions. ${ }^{9}$

The semantic dictionary is a construct that is very sensitive to negative changes taking place in the human body e. g. due to ageing ${ }^{10}$ or progressing neurodegenerative diseases ${ }^{11}$. This study in-

${ }^{5}$ Cognitive functions are also referred to as self-regulation functions that entail the organisation, control and management of other cognitice activities, emotional reactions and behaviour (conf. T. Morris, Urazy mózgu, [in:] „Neuropsychologia medyczna", ed. by C.L. Amstrong, L. Morrow, Polish edition edited by M. Harciarek, Wydawnictwo Lekarskie PZWL, Warszawa 2014, pp. 441-442). More on executive functions - see M. Pąchalska (Rehabilitacja neuropsychologiczna, Lublin 2014, pp. 370-382).

${ }^{6}$ The lexical activation hypothesis emerged on the basis of the semantic network model; in this view, semantic knowledge is stored as networks composed of numerous connections between various representations, referred to as nodes of semantic networks (conf. M. Kielar-Turska, K. Byczewska-Konieczny, Specyficzne wtaściwości postugiwania się językiem przez osoby w wieku senioralnym, [in:] „Biomedyczne podstawy logopedii", ed. by S. Milewski, J. Kuczkowski, K. Kaczorowska-Bray, Harmonia, Gdańsk 2014, pp. 437-440).

${ }^{7}$ Conf. M. Kielar-Turska, K. Byczewska-Konieczny, op. cit., pp. 430-433.

8 The name search strategy can take place according to a semantic key, e. g. for a semantic subcategory of a given semantic category, or according to a formal key, e. g. the first sound or syllable, etc.

${ }^{9}$ Conf. E.M. Szepietowska, B. Gawda, Ścieżkami..., op. cit., pp. 11-14; E.M. Szepietowska, B. Gawda, Werbalna fluencja afektywna i narracje emocjonalne u osób z choroba Alzheimera i demencja naczyniowa, „Psychogeriatria Polska” 2012, no. 9(1), pp. 38-39.

${ }^{10}$ Historic study results indicate that age is related to the number of errors when offering generative naming, meaning that as ageing progresses, the ability to create a list of semantically-related words worsens (conf. M. Rutkiewicz-Hanczewska, Wiek a nazywanie. Procesy wyszukiwania stów w starszym wieku, [in:] „Gerontologopedia", ed. by W. Tłokiński, S. Milewski, K. Kaczorowska-Bray, Gdańsk 2018, p. 248).

${ }^{11}$ Conf. W. Tłokiński, H. Olszewski, Zaburzenia mowy zwiazane z wiekiem, [in:] „Biomedyczne podstawy logopedii", ed. by S. Milewski, J. Kuczkowski, K. Kaczorowska-Bray, Gdańsk 2014, p. 415. 
clude an attempt to assess the condition of the semantic dictionary in persons with diagnosed mild cognitive impairment (MCI) in course of Parkinson's disease (PD).

\section{Parkinson's Disease}

Parkinson's Disease (ICD 10 - G20) is the second most frequent, after Alzheimer's Disease, neurodegenerative disease of the nervous system. In its case, the main cause of pathology is the death of a large number of dopaminergic neurons in the substantia nigra. ${ }^{12}$ Symptoms of PD include motor and extramotor dysfunctions. The first group includes e.g. bradykinesia (slowness of movement), muscle stiffness, shivers at rest, dysfunctions of posture movements. ${ }^{13}$ Extramotor symptoms include e. g. reduced speed of mental processes, weakened memory and the capacity to recall.14

In speech therapy of persons with PD, noted are mainly symptoms that are the effect of disarthria - most commonly hypokinetic, emerging as a result of damage to the extrapyramidal system. ${ }^{15}$

12 Conf. A.P. Krysiak, Zaburzenia jezyka i mowy i komunikacji w chorobie Parkinsona, „Neuropsychiatria i Neuropsychologia” 2011, no. 6(1), p. 36; W. Kozubski, P.P. Liberski, Neurologia, Wydawnictwo PZWL, Warszawa 2014, pp. 288-289; A. Friedman, Epidemiologia, rozpoznawane i leczenie choroby Parkinsona, [in:] "Zaburzenia poznawcze i psychiczne w chorobie Parkinsona i innych zespołach parkinsonowskich", ed. by T. Sobów, J. Sławek, Continuo, Wrocław 2006, p. 11.

13 W. Kozubski, P.P. Liberski, op. cit., pp. 287-288; A. Friedman, op. cit., p. 13. Symptoms supporting the diagnosis include e. g. dysarthria, hypomimia (limited facial expressions), akinesia (limited movement), dysfunction of the ability to quickly execute subsequent movemennts (conf. W. Kozubski, P.P. Liberski, op. cit., p. 289), (hence e. g. micrographia observed in a patient's handwriting).

14 Conf. A.P. Krysiak, op. cit., p. 36; W. Kozubski, P.P. Liberski, op. cit., pp. 288289; A. Friedman, op. cit., p. 11.

15 Conf. I. Gatkowska, Diagnoza dyzartrii u dorostych w neurologii klinicznej, Wydawnictwo UJ, Kraków 2012, p. 73; O. Jauer-Niworowska, J. Kwasiborska, Dyzartria. Wskazówki do diagnozy różnicowej poszczególnych typów dyzartrii, KOMLOGO, Gliwice 2009, p. 29, 33. 
It results in weakened activity of muscles responsible for motorics of articulation mechanisms, as well as breaching and dysfunctions. ${ }^{16}$

Ever improving efficiency of treatment of the motor symptoms of PD causes the extension of life of persons suffering from it. It is supposed that as the disease progresses, the frequency of extramotor symptoms increases, including cognitive dysfunctions. Their frequency ranges between $21 \%$ the moment PD is diagnosed up to $88 \%$ after seven years of disease progress. ${ }^{17}$ Language and speech dysfunctions apply to even $89 \%$ of patients, but only $3 \%$ participate in therapy aimed at reducing these symptoms. ${ }^{18}$

The presence of cognitive dysfunctions may lead to the development of mild cognitive impairments (MCI), and as a result - dementia ${ }^{19}$ even at an early stage of PD.

${ }^{16}$ Conf. A.P. Krysiak, op. cit., p. 36; Kozubski W., Liberski P.P., op. cit., pp. 287-288. Effects of muscle dysfunctions include e. g. dysprosody, expressed by: monotonous speech, lack of the capacity of voice modulation, voice decay, rhythm interference and lack of the possibility to accentuate, articulation dysfunctions. Observed is also a breathy or harsh voice or articulation, gradual reduction of the exhalation phase, and as a consequence, phase length, increased pauses and hesitation when speaking, and variable speech pace (reduction in case of damage to the globus pallidus, bradylalia, and quicker speech pace if there is damage to the striatum, tachylalia) conf. A.P. Krysiak, op. cit., p. 36; conf. also I. Gatkowska, op. cit., p. 76.

${ }_{17}$ D. Wieczorek, E.J. Sitek, J. Wójcik, J. Sławek, Łagodne zaburzenia funkcji poznawczych i otępienie w chorobie Parkinsona - obraz kliniczny i aktualne kryteria diagnostyczne, „Polski Przegląd Neurologiczny” 2013, no. 9(3), p. 96; J. Sławek, T. Sobów, R. Magierski, M. Boczarska-Jedynak, G. Opala, A. Gorzkowska, Zaburzenia neuropsychiatryczne, [in:] „Choroba Parkinsona i inne zaburzenia ruchowe”, ed. by J. Sławek, A. Friedman, A. Bogucki, G. Opala, Via Medica, Gdańsk 2012, p. 130.

${ }^{18}$ A.P. Krysiak, op. cit., p. 37, 39. Particularly complex are relationships between cognitive deficits and the duration of the disease and symptom intensity. Historic studies show the increase of cognitive dysfunctions as extrapyramidal symptoms increase, or the presence of memory and formal fluency dysfunctions at an early stage of PD with limited neurological symptoms, meaning a relative independence of motor and cognitive deficits, conf. E.M. Szepietowska, T. Hasiec, A. Jańczyk-Mikoś, Fluencja stowna $i$ niewerbalna $w$ różnych stadiach $i$ formach choroby Parkinsona, „Psychogeriatria Polska” 2012, no. 9(4), p. 139.

${ }^{19}$ Current diagnostic criteria for discovery of cognitive dysfunctions and dementia in PD were developed by the expert group Movement Disorder Society. They are presented in the paper of D. Wieczorek et al. (op. cit., p. 96). 
MCI is a set of clinical symptoms described as a transitional state between the correct ageing process and minor dementia. ${ }^{20}$ Mild cognitive impairment is of limited visibility in early stages of PD (meaning, $\leq 2$ stage on the Hoehn and Yahr scale ${ }^{21}$ ), however, they are among the most frequent causes of irreversible dementia ${ }^{22}$, hence the necessity of precise diagnosis to prevent the development of dementia. ${ }^{23}$

The most fundamental dysfuctions of PD-MCI, mild cognitive impairment in Parkinson's disease, include deficits in attention, operating memory and verbal fluency dysfunctions, in particular phonemic fluency (coupled with executive dysfunction), and semantic fluency to a lesser extent (related to verbal semantic memory). ${ }^{24}$ The deficits

${ }^{20}$ T. Gabrylewicz, Łagodne zaburzenia poznawcze, [in:] „Diagnostyka i leczenie otępień. Rekomendacje zespołu ekspertów Polskiego Towarzystwa Alzheimerowskiego", ed. by M. Zabawa, Medisfera, Otwock 2012, p. 51. Broader data on mild cognitive disorders is contained in the paper by L. Bidzian (Eagodne zaburzenia funkcji poznawczych, "Geriatria” 2015, no. 9, pp. 22-30; conf. also J. Sławek, T. Gabrylewicz, Otęienie w chorobie Parkinsona, [in:] „Diagnostyka i leczenie otępień. Rekomendacje zespołu ekspertów Polskiego Towarzystwa Alzheimerowskiego", ed. by M. Zabawa, Medisfera, Otwock 2012, pp. 114-122; conf. also T. Sobów, Zaburzenia poznawcze w chorobie Parkinsona, [in:] "Zaburzenia poznawcze i psychiczne w chorobie Parkinsona", ed. by T. Sobów, J. Sławek, Continuo, Wrocław 2006, pp. 75-85).

21 The Hoehn and Yahr scale us used to assess clinical progress of PD. The first stage is related to mild PD symptoms only on one side of the body, and minor psychomotor speed reduction; the fifth stage is found if the patient is not able to move independently or is confined to the bed (conf. M.M. Hoehn, M.D. Yahr, Parkinsonism: onset, progression and mortality, "Neurology” 1967, no. 17, pp. 427-442).

22 Conf. W. Kozubski, P.P. Liberski, op. cit., p. 263; H. Olszewski, Otępienie czołowo-skroniowe. Ujęcie neuropsychologiczne, Kraków, 2008, p. 183; G.M. Opala, Epidemiologia otepień w perspektywie prognoz demograficznych, [in:] „Choroby otępienne. Teoria i praktyka", ed. by J. Leszek, Wrocław 2003, p. 31.

${ }^{23}$ Assessment of PD uses the common numerical Unified Parkinson's Disease Rating Scale (UPDRD); it is used to access cognitive functions, the mental state and behaviour dysfunctions of patients, allows an assessment of motor skills, including the ability to perform daily tasks (R. Kazimierski, A. Niezgoda, Skale kliniczne w neurologii, [in:] „Neurologia. Podręcznik dla studentów medycyny”, ed. by W. Kozubski, P.P. Liberski, Warszawa 2014, p. 84).

${ }^{24}$ Conf. L. Bidzan, op. cit., pp. 25-26; J.E. Sitek, K. Kluj-Kozłowska, A. Barczak, Zaburzenia funkcji jezzykowych w atypowych zespołach parkinsonowskich, [in:] „Geronto- 
may also concern the pragmatic subsystem of language, including the capacity to take turns in a conversation, deliver feedback to the speaker, stay on topic, maintain statement style and conciseness. ${ }^{25}$

\section{Objective of the analysis}

The present analysis makes an attempt to evaluate verbal fluency in selected categories of common and proper names in persons with diagnosed mild cognitive impairment (MCI) without dementia, in the course of PD (PD-MCI).

Compared was the possibility of extraction of lexemes from the mental dictionary that are used to name items with multidesignate references - animal names (AN) and monodesignate references city names $(\mathrm{CN})$. An attempt was made to assess the influence on their "generation" of the fact that processes of searching for them take different brain pathways (which must be bound to different brain networks binding these names in the mental dictionary). ${ }^{26}$

The results of the executed tests were analysed qualitatively and quantitatively ${ }^{27}$. Evaluated was the time it took the patients to pro-

logopedia", ed. by W. Tłokiński, S. Milewski, K. Kaczorowska-Bray, Gdańsk 2018, p. 560. The basis for dysfunctions of executive functions is pathology of the frontostriatal circuit, mainly the thalamus and front portion of the circuit bend, and to a lesser extent the dorsolateral prefrontal circuit or the orbitofrontal part, considered to be the main anatomical substrates of executive capacities. Considered is also the relation between dysfunctions of executive functions and deficits of memory processes in course of PD covering declarative and non-declarative memory (conf. E.M. Szepietowska, T. Hasiec, A. Jańczyk-Mikoś, op. cit., p. 136. M. Pąchalska, op. cit., p. 272).

25 Conf. A.P. Krysiak, op. cit., p. 39.

${ }^{26}$ Literature assumes proper names are more difficult to learn and extract from the mental dictionary at any age (conf. M. Rutkiewicz-Hanczewska, Neurobiologia nazywania. O anomii proprialnej i apelatywnej, Wydawnictwo naukowe UAM, Poznań 2016, p. 28).

${ }^{27}$ Quantitative norms were developed for the Polish language only for selected samples and age groups. This study assumes that the norm for broad categories is 15 words (after M. Piskunowicz et al., op. cit., p. 479). 
duce the first name. Assessed was the result of so-called word production, e. g. the number of correct answers and errors (with their properties described). The strategy of generation of bunches of related words - clusters ${ }^{28}$ - was described, their content was analysed, their size - assessed. Phenomena were indicated and described that influence the results in verbal fluency, such as OTV (off target verbosity) or TOT (tip-of-the-tongue) ${ }^{29}$, as well as the forms of amendment of verbal messages as a result of word readiness reduction. Observations were referred back to the results of the control group, and then related to possible causes of reduction in verbal fluency; the process specifics were described.

\section{Method}

The study had two stages. During the first, medical documentation and anamneses ${ }^{30}$ were used to select the study and control group. I conducted the MMSE for both groups - it is a fundamental test allowing one to evaluate cognitive functioning, to achieve relevant certainty: the presence of mild cognitive impairments without signs of dementia in the group of persons diagnosed with PD and

28 The presence of clusters, the basis of which are semantic ties, indicates welldeveloped/ maintained semantic networks in the mental dictionary. Clusters in fluency tests can also be created using formal keys - when at least two words begin with the same sound or syllable (conf. Piskunowicz et al. 2013, op. cit., p. 476). It is assumed that tasks of semantic fluency more strongly engage temporal lobes, and those of formal fluency - frontal lobes - executive functions. The criterion choice for the establishment of a cluster indicates the thinking strategy (A.K. Troyer, M. Moscovitch, G. Winocur, M.P. Alexander, D. Stuss, Clustering and switching on verbal fluency: the effects of focal frontal and temporal-lobe lesions, "Neuropsychologia” 1998, no. 36, pp. 138-146).

${ }^{29}$ More on the tip-of-the-tongue syndrome, see M. Rutkiewicz-Hanczewska (Wiek..., op. cit., pp. 244-246).

30 The anamnesis was used to register data on education, professional activity, language, lateralisation and the will to participate in the study. 
no cognitive disorders in the control group. The second stage involved the verbal fluency test.

I commanded the analysed individual as follows: please state as many animal names as possible (followed by names of cities, always in the same order). I made sure the studied person understood the order. I made no pauses between the trials, because I evaluated whether perseveration occurred (returning to the preceding task). ${ }^{31}$ 60 seconds were allotted for the task. ${ }^{32}$

I did not intervene in the trials, save for situations if the studied individual asked for the command to be repeated, or if they asked whether a particular word was already named (my replies being yes or no). I took to recording both interventions, as they might indicate memory dysfunctions. Questions by the studied individual whether a word fulfils the task criteria were responded to with the information that the word was recorded, so as not to suggest what type of response I expected.

\section{Characteristics of the studied persons}

The study used data collected in the years 2014-2018 at a care and treatment facility and at a speech therapy practice. The study spanned 32 people classified in two groups. The first, of seventeen

31 They indicate dysfunctions of membery and task control mechanisms (conf. Pąchalska, op. cit., pp. 395-397).

32 Usually, the execution of individual tasks in terms of verbal fluency use 60 seconds (conf. B. Daniluk, E.M. Szepietowska, Ptynność semantyczna i literowa osób w różnych fazach dorosłości - czynniki modyfikujące wykonanie zadań fluencji stownej część II, "Annales Universitatis Mariae Curie-Skłodowska. Sectio J: Paedagogia-Psychologia" 2009, no. 22, pp. 383-405; U. Stolarska, S. Kroczka, A. Gergont, M. Steczkowska, M. Kaciński M., Test fluencji stownej - aspekty rozwojowe w normie i patologii, „Przegląd Lekarski” 2008, no. 65, p. 765; B. Daniluk, E.M. Szepietowska, Ptynność semantyczna i literowa osób w różnych fazach dorostości - część I, "Annales Universitatis Mariae Curie-Skłodowska. Sectio J: Paedagogia-Psychologia” 2009, no. 22, pp. 97-110), the time limit is extended to two minutes in case of significant psychomotor reduction (conf. E.M. Szepietowska, B. Gawda, Ścieżkami..., op. cit., p. 12). 
people, are patients with diagnosed mild cognitive disorders in course of Parkinson's disease (GPD-MCI), the second 15-person group is the control group (CG).

The analysed persons formed groups "naturally”, meaning, according to the dynamics of admission to the facilities. Everyone consented to the study. ${ }^{33}$

The age of persons in both groups remained in the range of 67-75 years. ${ }^{34}$ Due to the lack of clear data on the influence of gender $^{35}$ on the test results, the study analysis did not account for gender differences ${ }^{36}$. Nobody was professionally active, everyone was right-handed, Polish, with vocational or secondary-school education. ${ }^{37}$

Before the commencement of the verbal fluency test, the patients did not participate in therapy for the purpose of improving it.

The PD-MCI group was selected based on medical documentation and anamneses. The study included persons: 1) with diagnosed Parkinson's Disease; 2) with a MMSE score of 26-24; 3) without depressions or with mild depression (per the GSD)38; 4) in the first or second stage of PD per the Hoehn and Yahr scale. Excluding criteria

33 Data was collected in line with rules on personal data protection.

34 The relationship is assumed that age is inversely proportional to verbal fluency (conf. Szepietowska, Gawda, Ścieżkami..., op. cit., p. 26; J.K Bolla, S. Gray, S.M. Resnick, R. Galante, C. Kawas, Category and letter fluency in highly educated older adults, „The Clinical Neuropsychologist” 1998, no. 123, pp. 330-338).

35 More on studies on the influence of gender on verbal fluency test results, see M. Szepietowska, B. Gawda, (Ścieżkami..., op. cit., pp. 30-31).

36 In GPD-MCI 86\% were male and 14\% female; in CG $81 \%$ were male and $19 \%$ female.

${ }^{37}$ Historic studies assumed a relation between high scores in the verbal fluency test and higher formal education. A broader vocabulary related to education corresponds to more efficient execution of verbal fluency tasks, conf. Szepietowska, Gawda, Ścieżkami..., op. cit., p. 29.

38 Test results suggest that patients with stronger depression assess their cognitive difficulties as higher as compared to actual results, in comparison to results of observations of their caretakers (E.M. Szepietowska, B. Gawda, Werbalna..., op. cit., p. 139). 
were: 1) generalised infections; 2) electrolyte problems, thyroid gland insufficiency, vitamin B12 shortage; 3) hallucinations; 4) current medications influencing cognitive functioning (save for levodopaminergic medications) ${ }^{39}$; 5) other dysfunctions/ factors not related to the PD that could influence the VF test score.

The control group was made up of persons who: 1) received an MMSE score above 26 ; 2 ) are patients of internal medicine or geriatric wards or care and treatment facilities for reasons other than dysfunctions caused by any CNS diseases, mental diseases or other illnesses that significantly influence the execution of verbal fluency tasks.

\section{Results and analysis of the verbal fluency test}

\section{Animal names}

The studied persons from the PD-MCI group listed on average nine names (top scopre 16, lowest four!), of which on average $77 \%$ were correct (no repetitions or semantic errors). In the CG the mean score was 22 (top 30, lowest 13) of which ca. 90\% fulfilled the criteria.

The first name in the PD-MCI group was recalled within ca. 5-15(!) s. At first and during the task, observed was a significant reduction of thinking speed in the studied persons, indicating reduced quality of processes of searching through semantic memory resources, limited capacity to initiate purposeful activity and slowdowns in cognitive processing. ${ }^{40}$ Highest productivity was observed between the 10th and the 20th second. Even though none of the studied persons declined participating in the trial, patients of this group reacted significantly worse to the task than those of the CG.

${ }^{39}$ Pharmacological therapy can have a negative influence on cognitive functioning, hence, also on verbal fluency of PD patients. More on the influence of drugs on cognitive functioning, see J. Sławek et al. (Zaburzenia ..., op. cit., pp. 130-171).

${ }^{40}$ Conf. M. Piskunowicz et al., op. cit., p. 477. 
The awareness of the vastness of the set, with simultaneous impossibility of reaching its entries caused the studied patients to finish the task quickly by stating that they do not remember any more animals, and, lacking access to further names, most commonly ceased to attempt searching their semantic dictionary (over half of the studied patients) e. g. ...well... no more animals; I already named the bear... that's the end. I don't have any more; what else? What now?; that's it...; that's... that's... about it.

The patients from the CG used all the time allotted for the trial. They recalled the first name much more quickly, e. g. within 1-2 s. Highest productivity was observed between ca. $30-40$ seconds. The speed of finding the first and subsequent names and their mean number indicates a quicker speed of searching the semantic dictionary and of its larger size. It may also prove that processes of initiation of purposeful activity and cognitive processing are more efficient than in GPD-MCI.41

Nobody from either group required the task content to be repeated, indicating quite well-functioning short-term memory.

Semantic errors emerged in strings produced by patients from both groups, but they dominated in GPD-MCI. These were so-called superordinate category errors - subcategory names, e. g. ...fish...; ...fish in general...; ...birds...; ...dog, cat, what else is there... reptiles? Such errors indicate the possibility of reaching the name describing the prototypical properties of that semantic category, without access to words fulfilling the properties of this prototype. 42 Their presence may suggest semantic dysfunctions as the use of superordinate „labels" for a broad range of various units may indicate that the categorisation process stops at the boundary of hierarchy that is disintegrated, with the components closest to the boundary most susceptible to dysfunctions. ${ }^{43}$ This phenomenon is related to a drop

${ }^{41}$ M. Piskunowicz et al., op. cit., p. 477.

42 Conf. E.M. Szepietowska, J. Lipian, Fluencja słowna neutralna i afektywna u chorych z uszkodzeniem prawej, lewej lub obu pótkul mózgu, „Psychiatria Polska” 2012, no. XLVI, 4, p. 541.

${ }^{43}$ H. Olszewski, op. cit., p. 110. 
Verbal fluency in categories of common and proper names in the phase of mild 261

in so-called mental flexibility and attention divisibility that are to be linked with executive functions and working memory ${ }^{44}$, more generally - with frontal lobe activity. ${ }^{45}$

At times, a consequence of the observed lack of word readiness (TOT) were descriptive structures, e. g. that... red one, you know, dear; chicken..., okay, rooster... and the grand one... that gobbles?..., these were sporadic, mainly I the GPD-MCI (ca. 1\%).

Repetitions - a phenomenon characteristic for the described age group ${ }^{46}$ - were found in both groups. In GPD-MCI, however, there was a tendency to repeat the superordinate category name at the start of the task (46\% of patients) e. g. animals...; animals... cat, dog; some animals... This phenomenon is most probably related to the mode of excitation of semantic fields - the semantic activation mechanism. Patients from the CG did not use it at the start of the task, they used this mechanism during the trial, when lacking access to a further desired word.

Among all repetitions emerging in responses by patients from the PD-MCI group, patients were aware of ca. $65 \%$ of them, e. g. lion, tiger, cheetah..., lion... I had that already; ... hamster, mouse, rat, what else... duck, chicken, rooster, hamster, had that [...]; the remaining repetitions went unnoticed. Literature says that Parkinson's disease at an early stage causes quite rarely difficulties in retaining in memory the results of cognitive decisions and dysfunctions of mechanisms controlling a task course ${ }^{47}$, hence the number of recorded repetitions was not significantly higher than in the control group; here they constituted a total of ca. $5 \%$ of all responses (most commonly the persons were aware of them [90\%], as

${ }^{44}$ Conf. B. Rende, G. Ramsberger, A. Miyake, Commonalities and differences in the working memory components underlying letter and category fluency task: A dual task investigation, "Neuropsychology" 2002, no. 16, pp. 309-321.

45 A.K. Troyer, M. Moscovitch, G. Winocur, M.P. Alexander, D. Stuss, Clustering and switching on verbal fluency: the effects of focal frontal and temporal-lobe lesions, "Neuropsychologia" 1998, no. 36, pp. 138-146.

46 Conf. M. Kielar-Turska, K. Byczewska-Konieczny, op. cit., p. 437.

${ }^{47}$ Conf. A.P. Krysiak, op. cit., p. 38. 
indicated by comments like: I already said that; already had that; already given).

One of the mechanisms aimed at encouraging the mental dictionary search process is referring to so-called fillers, e. g. single or multiple repetitions of an earlier word or of words; their presence indicates reduced efficiency of searching the mental dictionary, but at the same time it simplifies the activation of semantic fields related to the generated words his type of shortage of fluency must be distinguished from repetitions named above. Fillers, even though present and numerous in strings generated by patients from GPD-MCI (ca. $10 \%$ of all responses), did not significantly influence the improvement of results, as they were rarely followed by bunches of words or single words semantically or phonologically tied to the words sought after, e.g. herring, mackerel..., mackerel..., herring..., mackerel...; ...chicken... chicken... chicken..., seal; duck, chicken..., duck, chicken... fish. In CG fillers were less numerous, and their use was related to recalling words similar in the semantic or phonological sense, e. g. [...] stork, sparrow, tit, swallow... swallow... hawk...

The phenomenon of "off-target verbosity" (OTV) ${ }^{48}$, typical for the analysed age group and possibly related to a deficit of the capacity to limit insignificant information that does not fulfil the task criteria, was noted only in the CG, e. g. cows, horses, calves, bull and others... chickens... we had these animals, there was a lot of work with them, and what else... dog [...]; dog, cat, I always had dogs and kittens, ooh, all kinds of breeds [the patient laughs], and the boar, fox, roe [...]. However, the focus on the task objective related to this was not observed. The responses by patients from GPD-MCI did not see any tendencies to relate to their life experiences, and this is most probably related to a reduction of discourse and spontaneous speech characteristic for PD. ${ }^{49}$

48 The phenomenon is quite characteristic for the elderly, also without brain pathologies (conf. Kielar-Turska, Byczewska-Konieczny, op. cit., p. 432).

${ }^{49}$ J.E. Sitek et al., op. cit., p. 562. 
Verbal fluency in categories of common and proper names in the phase of mild 263

The responses of the patients indicated minor numbers of diminutives ${ }^{50}$, e. g. kittens, doggies, cowies, doggies, and if there's a doggie, there is a kitten, without any significant domination by any group. There was also no significantly differentiating volume of names used in the plural (this subjectively increases the perceived number of quoted names) e. g. chickens, roosters, ducks (PD-MCI).

As expected, the GPD-MCI included much fewer clusters than the CG, statistically just a little over two per patient (lowest one, highest four clusters) with CG scoring almost six on average (lowest two, highest 12). In the GPD-MCI, the number of related (in clusters) and unrelated names was statistically compatible, indicating a reduced capacity to search for a strategy of name generation. The patients quickly ran out of resources of names belonging to indicated subcategories. A result of the drop of cognitive flexibility were significant difficulties in switching over to a further subcategory and recalling unrelated names, e. g. chicken, rooster, roe, sparrow, most probably related to low cluster diversity. Patients would most commonly name pets, e. g. dog, cat; dog, cat, hamster; farm animals, e. g. goat, sheep..., sheep... ram, much less forest animals, e. g. wolf, boar, or African animals, e. g. lion, elephant, crocodile; lion, giraffe. Some patients used the phonetic strategy to search for names, e. g. the k sound: cow, crocodile, cat; the b sound: bull, bison, bear.

In CG, cluster spanned 12 subcategories (including farm animals, pets, birds, exotic animals, fish, reptiles, mammals, forest animals). A significant number of clusters indicates an efficiently operating semantic activation mechanism. The presence of clusters, the basis of which is a formal key, e. g. the k sound: cow, cat, crow, crocodile, cockatoo; similarly, within specific semantic categories: cow, cock, cat, proves that executive functions are efficient; it also suggests quite high cognitive flexibility allowing a change of the strategy if a further name is inaccessible.

50 A significant proportion of diminutives may indicate progressive speech infantilisation. 
Table no. 1. Source: Own work

\begin{tabular}{|l|c|c|}
\hline \multicolumn{1}{|c|}{ Animal names } & GPD-MCI & CG \\
\hline Statistic number of responses per studied patient & 9 & 22 \\
\hline Number of correct names among the responses provided & $77 \%$ & $90 \%$ \\
\hline Semantic errors among all responses & $5 \%$ & $0,2 \%$ \\
\hline Descriptive structures & $2 \%$ & $0,2 \%$ \\
\hline Repetitions among all responses & $6,5 \%$ & $5 \%$ \\
\hline Fillers among all responses & $10 \%$ & $5 \%$ \\
\hline Mean number of clusters per patient & ca. 2 & ca. 6 \\
\hline Mean cluster capacity & ca. 3 names & ca. 6 names \\
\hline
\end{tabular}

\section{City names}

The patients from the GPD-MCI listed on average 14 names, of which $89 \%$ were names fulfilling the task criteria (lowest score six, highest 21 names). In CG, the mean result was 19 names, of which $90 \%$ were correct (lowest five, highest 30 names).

Patients from the GPD-MCI recalled the first name within the first 4-10 seconds. Highest productivity was observed until about 25 seconds. The patients did not utilise all their time allotted for the trial, independently concluding the task ahead of time (ca. $70 \%$ patients), e. g. Warszawa, Łódź, Łowicz..., Kraków, Katowice, Konin, Konin... that's it, I can't recall any more; [...] Eódź, Warszawa, Zamość... that's it; [...] Poznań, Pabianice, my God there are so many and I forgot'em all..., no, there aren't gonna be any more; [...] I don't know any more, this is so silly of you, I don't know... In CG the first name was recalled within 1-3 seconds. Highest productivity was observed up to ca. 30 seconds. The patients used all the time allotted for the trial.

No semantic errors were recorded in either group. This may certainly be explained by the specifics of the propria51 and suggests

51 Nomina propria are characterised by e. g. singularity, describing, not adjudicating on the reference, information entropy, narrow denotation, broad connotation and the identifying, indicative function. Nomina appellativa primarily have meaning, are characterised by information redundancy, broad denotation and narrow conno- 
Verbal fluency in categories of common and proper names in the phase of mild 265

more efficient storage of city names in the mental dictionaries of the tested patients.

Numerous descriptive structures were found, a result of TOT. Their presence may prove that the patients had easier access to semantic knowledge on the name searched for, e. g. that small place near here, they make good milk and cheese there... I don't remember... that's it. The quote shows that the patient did not have access to phonological knowledge on the desired name and abandoned searching for it quite quickly. The majority of test results show that patients from the healthy population, when they gain access to certain metacognitive data on the word sought for, continue searching for it, hoping for success. ${ }^{52}$

Repetitions were quite frequent. In both groups they formed a comparable part of responses. In GPD-MCI repetitions that patients weren't aware of were statistically more common (ca. 5\%) e.g. Wrocław, Warszawa, Wieliczka, Kraków, Poznań, Toruń, Warszawa [...]; Kalisz and then... what can we name...? then maybe now... [after ca. 15 s.] Kalisz, indicating dysfunctions of short-term memory and dysfunctions of executive functions, the task of which is controlling the correctness of task execution against the set criteria. Less numerous were repetitions indicating lack of certainty whether a name was already given, e. g. [...] did I say Wałbrzych? [...]; [...] did I say Kraków? [...].

In this category as well, patients from the GPD-MCI had a tendency to repeat the order at the beginning of the task. saying e. $g$. city names...; some city names..., this phenomenon, as stated above, can be related to the mode of excitation of the semantic dictionary. In $\mathrm{CG}$, this tendency was observed only during task execution, if a further desired word was not accessible.

Fillers were more frequent in CG, making up ca. 5\% of answers, in GPD-MCI ca. 3\%.

Perseveration - returning to the previous task - was not found in any group.

tation, they have a symbolic, categorising function (conf. M. Rutkiewicz-Hanczewska, Neurobiologia..., op. cit., p. 16).

52 Conf. M. Rutkiewicz-Hanczewska, Wiek ..., op. cit., p. 246. 
Category clusters for cities were significantly more numerous in CG (lowest six, highest 15) than in GPD-MCI (lowest two, highest five). In GPD-MCI, the semantic strategy of name-searching prevailed, with patients naming e.g. voivodeship capitals, capitals or seaside cities, e. g. Warszawa, Kraków; Kołobrzeg, Gdańsk, Gdynia, Sopot; Łódź, Warszawa. They used a formal key of searching to a lesser extent, e.g. Warszawa, Wrocław; Ostrów Mazowiecki, Ostrów Wielkopolski, Ostrów Lubelski; Radomsko, Radom; Nowy Sącz, Nowy Targ. CG saw the domination of the phonetic strategy when searching for names - based on the first sound, syllable or part of the name, e. g. Warszawa, Wroctaw, Wieliczka, Watbrzych; Katowice, Kalisz; Tomaszów Mazowiecki, Tomaszów Lubelski. The patients, using the semantic strategy, listed most frequently capital city names, e. g. Paris, Rome, seaside cities: Gdańsk, Gdynia, Sopot; cities related to known destinations.

Table no. 2. Source: Own work

\begin{tabular}{|l|c|c|}
\hline \multicolumn{1}{|c|}{ City names } & GPD-MCI & CG \\
\hline Statistic number of responses per studied patient & 14 & 19 \\
\hline Number of correct names among the responses provided & $89 \%$ & $90 \%$ \\
\hline Semantic errors among all responses & $0 \%$ & $0 \%$ \\
\hline Descriptive structures & $0,8 \%$ & $0 \%$ \\
\hline Repetitions among all responses & $7 \%$ & $6 \%$ \\
\hline Fillers among all responses & $3 \%$ & $4,5 \%$ \\
\hline Mean number of clusters per patient & ca. 2 & ca. 3 \\
\hline Mean cluster capacity & ca. 2-3 names & ca. 3-5 names \\
\hline
\end{tabular}

\section{Summary}

The presented study results are not conclusive, as the study only used a small group, however, they allow for the formulation of conclusions with respect to it and are an introduction to further research on a larger patient group. 
Patients from both groups had no trouble understanding the task, nobody asked for the task to be repeated, hence, no working memory deficiencies were observed (they may accompany PD). 53

Irrespective of the task type, in GPD-MCI there was a significant problem with the first name and a reduction in course of the task (so-called bradyphrenia). Observed difficulties with initiation of activity and control of the task course, difficulty changing the cognitive attitude, may be bound to dysfunctions of executive functions. ${ }^{54}$ The patients searched a bit more quickly for city names, and the highest productivity period was slightly longer than for the animal name category. In CG these values were comparable in both categories and provide no differentiation.

Patients from the PD-MCI group did not use the entire time allotted for the task, as patients from the CG did. One may conclude that the core of observed deficits seems to lie in motivation and execution dysfunctions, and this behaviour cannot be linked to disorders of attention selectiveness, the possibility to maintain it or control dysfunctions. 55

The quantitative analysis of the results shows that patients from the GPD-MCI reached higher word production scores for the city name category than for the animal name category. Historic references concerning the possibility of generative and confrontational naming of common and proper names suggest lower "accessibility" of propria (with the studies, however, mainly applying to first and last names). ${ }^{56}$ Difficulty recalling them is explained by specific phonological properties of the propria, which, as arbitrary, offer less excitation as compared to common names, which have numerous semantic ties (so-called transmission deficit). ${ }^{57}$ The observed diver-

${ }^{53}$ Conf. M. Pąchalska, op. cit., pp. 256-264; J.E. Sitek et al., op. cit., p. 561.

54 Conf. J.E. Sitek et al., op. cit., p. 560.

55 The process of control is the process of assigning resources to a task, requiring conscious decisions on what should be provided with attention in any given moment (conf. M. Pąchalska, op. cit., p. 212).

${ }^{56}$ Conf. M. Rutkiewicz-Hanczewska, Neurobiologia..., op. cit., pp. 251-253.

${ }^{57}$ Conf. M. Kielar-Turska, K. Byczewska-Konieczny, op. cit., pp. 439-440; M. Rutkiewicz-Hanczewska, Wiek..., op. cit., p. 205. 
gence suggests at least comparable access capacity for city names and common names. However, this conclusion requires observation on a larger study group.

In both tasks, patients from the GPD-MCI achieved scores below the norm. The minor number of terms actualised according to the set semantic criteria indicates a dysfunction of semantic memory and suggests pathology of the temporal lobes.

Semantic errors in both groups were characteristic only for common names; this stems most probably from the systemic properties of common and proper names. There were no instances of generation of names outside of the categories as a result of switching to a different search criterion that would be more easily available at the time of searching.

As a percentage, descriptive structures comprised a minor fraction of all responses and were more common in the common name category. They indicate inaccessibility of the word sought after, but indicate the process of active vocabulary browsing and the will to complete the task.

The number of repetitions basically does not offer differentiation between tasks or groups.

Fillers in the GPD-MCI were more frequent in the category of common names. They indicate inaccessibility of the word sought after and are a sort of mechanism exciting the process of active semantic dictionary browsing. Inn CG their number was comparable for both tasks.

A significant factor differentiating the groups, irrespective of the task criterion, was the size and capacity of the generated clusters their count is considered to be a score indicating cognitive flexibility, and the size is considered a measure of the efficiency of browsing semantic memory. ${ }^{58}$ Test results indicate that the presence of MCI may be linked to a drop in the count and capacity of clusters. This suggests a progressive process of reduction of the mind dic-

58 E.M. Szepietowska, B. Gawda, Ścieżkami..., op. cit., p. 12; E.M. Szepietowska, B. Gawda, Werbalna..., op. cit., p. 136. 
tionary, hence, a slow decay of semantic categories. Limited flexibility in movement from one semantically or phonologically related group of words to another (so-called switches) is to be linked with executive function insufficiencies.

Patient responses did not show echolalia, palilalia, perseveration or neologisms. Not noted was also lack of fluency when producing further words or errors in word structures that could indicate decay of automated language forming processes.

To summarise - one could find several causes for low scores in the VF test result for the PD-MCI group, with the most significant seemingly dysfunction of organisation and strategy of thinking (related to the loss of general cognitive flexibility, executive function insufficiencies and memory as well as attention dysfunctions). ${ }^{59}$ They concern, to a lesser extent, the decay of semantic networks and a gradual reduction of the semantic dictionary. The test results must also be analysed in the context of dysfunctions in the cognitiveemotional-motivational area. ${ }^{60}$

\section{Bibliography}

[1] Bidzan L., Łagodne zaburzenia funkcji poznawczych, "Geriatria” 2015, no. 9, pp. 22-30.

[2] Bolla J.K., Gray S., Resnick S.M., Galante R., Kawas C., Category and letter fluency in highly educated older adults, "The Clinical Neuropsychologist” 1998, no. 123, pp. 330-338.

[3] Daniluk B., Szepietowska E.M., Płynność semantyczna i literowa osób w różnych fazach dorostości - część I, "Annales Universitatis Mariae Curie-Skłodowska. Sectio J: Paedagogia-Psychologia" 2009, no. 22, pp. 97-110.

[4] Daniluk B., Szepietowska E.M., Płynność semantyczna i literowa osób w różnych fazach dorostości - czynniki modyfikujące wykonanie zadań fluencji stownej - część II, "Annales Universitatis Mariae Curie-Skłodowska. Sectio J: Paedagogia-Psychologia" 2009, no. 22, pp. 111-128.

${ }^{59}$ Conf. K. Jodzio, Neuropoznawcze korelaty spadku fluencji stownej po udarze prawej pótkuli mózgu, „Studia Psychologiczne” no. 44(2), 2006, p. 15; conf. also E.M. Szepietowska, T. Hasiec, A. Jańczyk-Mikoś, op. cit., p. 136.

${ }^{60}$ Conf. E.M. Szepietowska, T. Hasiec, A. Jańczyk-Mikoś, op. cit., p. 136. 
[5] Friedman A., Epidemiologia, rozpoznawane i leczenie choroby Parkinsona [in:] „Zaburzenia poznawcze i psychiczne $\mathrm{w}$ chorobie Parkinsona i innych zespołach parkinsonowskich", ed. by T. Sobów, J. Sławek, Continuo, Wrocław 2006, pp. 11-23.

[6] Gabrylewicz T., Łagodne zaburzenia poznawcze [in:] „Diagnostyka i leczenie otępień. Rekomendacje zespołu ekspertów Polskiego Towarzystwa Alzheimerowskiego", ed. by M. Zabawa, Medisfera, Otwock 2012, pp. 50-57.

[7] Gatkowska I., Diagnoza dyzartrii u dorostych w neurologii klinicznej, Wydawnictwo UJ, Kraków 2012.

[8] Hoehn M.M., Yahr M.D., Parkinsonism: onset, progression and mortality, „Neurology" 1967, no. 17, pp. 427-442.

[9] Jauer-Niworowska O., Kwasiborska J., Dyzartria. Wskazówki do diagnozy różnicowej poszczególnych typów dyzartrii, KOMLOGO, Gliwice 2009.

[10] Jodzio K., 2006, Neuropoznawcze korelaty spadku fluencji stownej po udarze prawej pótkuli mózgu, „Studia Psychologiczne” no. 44(2), 2006 pp. 5-18.

[11] Kazimierski R., Niezgoda A., Skale kliniczne w neurologii, [in:] „Neurologia. Podręcznik dla studentów medycyny", ed. by W. Kozubski, P.P. Liberski, Warszawa 2014, pp. 83-85.

[12] Kielar-Turska M., Byczewska-Konieczny K., Specyficzne wtaściwości postugiwania się jezzykiem przez osoby w wieku senioralnym, [in:] „Biomedyczne podstawy logopedii", ed. by S. Milewski, J. Kuczkowski, K. Kaczorowska-Bray, Harmonia, Gdańsk 2014, pp. 429-443.

[13] Kozubski W., Liberski P.P., Neurologia, Wydawnictwo PZWL, Warszawa 2014.

[14] Krysiak A.P., Zaburzenia jezyka i mowy i komunikacji w chorobie Parkinsona, „Neuropsychiatria i Neuropsychologia" 2011, no. 6(1), pp. 36-42.

[15] Łuczywek E., Fersten E., Poziom fluencji stownej przy różnych uszkodzeniach mózgu, "Studia Psychologiczne" 1992, no. XXX, 1-2, pp. 89-98.

[16] Morris T., Urazy mózgu [in:] „Neuropsychologia medyczna”, ed. by C.L. Amstrong, L. Morrow, Polish edition edited by M. Harciarek, PZWL Wydawnictwo Lekarskie, Warszawa 2014, pp. 27-53.

[17] Olszewski H., Otępienie czotowo-skroniowe. Ujęcie neuropsychologiczne, Kraków 2008.

[18] Opala G. M., Epidemiologia otępień w perspektywie prognoz demograficznych, [in:] "Choroby otępienne. Teoria i praktyka", ed. by J. Leszek, Wrocław 2003, pp. 19-26.

[19] Pąchalska M., Rehabilitacja neuropsychologiczna, Lublin 2014.

[20] Piskunowicz M., Bieliński M., Zgliński A., Borkowska A., Testy fluencji stownej - zastosowanie w diagnostyce neuropsychologicznej, „Psychiatria Polska” 2013, no. XLVI, 3, pp. 475-485.

[21] Ponichtera-Kasprzykowska M., Sobów T., Adaptacja i wykorzystanie testu fluencji stownej na świecie, „Psychiatria i Psychologia Kliniczna” 2014, 14(3), pp. 178-187. 
[22] Rende B., Ramsberger G., Miyake A., Commonalities and differences in the working memory components underlying letter and category fluency task: A dual task investigation, "Neuropsychology” 2002, no. 16, pp. 309-321.

[23] Rutkiewicz-Hanczewska M., Neurobiologia nazywania. O anomii proprialnej $i$ apelatywnej, Wydawnictwo naukowe UAM, Poznań 2016.

[24] Rutkiewicz-Hanczewska M., Wiek a nazywanie. Procesy wyszukiwania stów w starszym wieku, [in:] „Gerontologopedia”, ed. by W. Tłokiński, S. Milewski, K. Kaczorowska-Bray, Gdańsk 2018, pp. 241-269.

[25] Sitek J.E., Kluj-Kozłowska K., Barczak A., Zaburzenia funkcji językowych w atypowych zespołach parkinsonowskich, [in:] „Gerontologopedia”, ed. by W. Tłokiński, S. Milewski, K. Kaczorowska-Bray, Gdańsk 2018, pp. 556-572.

[26] Sławek J., Gabrylewicz T., Otepienie w chorobie Parkinsona, [in:] „Diagnostyka i leczenie otępień. Rekomendacje zespołu ekspertów Polskiego Towarzystwa Alzheimerowskiego", ed. by M. Zabawa, Medisfera, Otwock 2012, pp. 50-57.

[27] Sławek J., Sobów T., Magierski R., Boczarska-Jedynak M., Opala G., Gorzkowska A., Zaburzenia neuropsychiatryczne, [in:] „Choroba Parkinsona i inne zaburzenia ruchowe", ed. by J. Sławek, A. Friedman, A. Bogucki, G. Opala, Via Medica, Gdańsk 2012, pp. 130-171.

[28] Sobów T., Zaburzenia poznawcze w chorobie Parkinsona, [in:] „Zaburzenia poznawcze i psychiczne w chorobie Parkinsona", ed. by T. Sobów, J. Sławek, Continuo, Wrocław 2006, pp. 75-85.

[29] Stolarska U., Kroczka S., Gergont A., Steczkowska M., Kaciński M., Test fluencji stownej - aspekty rozwojowe w normie i patologii, "Przegląd Lekarski” 2008, no. 65, pp. 764-768.

[30] Szepietowska E.M., Gawda B., Ścieżkami fluencji werbalnej, Wydawnictwo UMCS, Lublin 2011.

[31] Szepietowska E.M., Gawda B., Werbalna fluencja afektywna i narracje emocjonalne u osób z chorobą Alzheimera i demencją naczyniowa, „Psychogeriatria Polska” 2012, no. 9(1), pp. 37-46.

[32] Szepietowska E.M., Hasiec T., Jańczyk-Mikoś A., Fluencja słowna i niewerbalna w różnych stadiach i formach choroby Parkinsona, "Psychogeriatria Polska” 2012, no. 9(4), pp. 137-148.

[33] Szepietowska E.M., Lipian J., Fluencja słowna neutralna $i$ afektywna u chorych z uszkodzeniem prawej, lewej lub obu półkul mózgu, „Psychiatria Polska” 2012, no. XLVI, 4, pp. 539-551.

[34] Thurstone L.L., Mental abilities, Chicago 1938.

[35] Tłokiński W., Olszewski H., Zaburzenia mowy zwiąane z wiekiem, [in:] „Biomedyczne podstawy logopedii", ed. by S. Milewski, J. Kuczkowski, K. Kaczorowska-Bray, Gdańsk 2014, pp. 410-428.

[36] Troyer A.K., Moscovitch M., Winocur G., Alexander M.P., Stuss D., Clustering and switching on verbal fluency: the effects of focal frontal and temporal-lobe lesions, „Neuropsychologia” 1998, no. 36, pp. 499-504. 
[37] Wieczorek D., Sitek E.J., Wójcik J., Sławek J., Łagodne zaburzenia funkcji poznawczych $i$ otepienie w chorobie Parkinsona - obraz kliniczny i aktualne kryteria diagnostyczne, „Polski Przegląd Neurologiczny” 2013, no. 9(3), pp. 96-104.

[38] Zawadzka E., Świat w obrazach u osób po udarze mózgu, Wydawnictwo DIFIN, Warszawa 2013. 